\section{Education issues in Japan}

ONE of the most commonly quoted It is the structural unit of the faculty, statistics about Japanese higher educa- responsible for education and research tion is that graduates comprise only in a specific subject area, and is comabout $3 \%$ of total student numbers posed basically of one professor, one (compared, say, with the UK where assistant professor and two assistants. graduates comprise $20 \%$ of all It is provided with its own running students). What is less often mentioned expenses and facilities. Although often is that even this $3 \%$ meant 46,000 criticised as an idestructible castle of graduate students in 1973-more than conservation and hierarchy, it funcin the UK. Even so, the concept of the tioned reasonably well in the pre-war graduate course as an integral part of imperial university, and has also been the structure of a university is less fitted into the present frame-work of common in Japan. As the table shows, graduate education. Partly because of half of all universities do not have such the rapid expansion of the size of encourses.

Since the Second World War the number of universities in Japan has increased enormously. For national universities the government took the view that newly established institutions should not have graduate courses; rather, the courses in the former im- as well as research more flexible and perial universities should be enlarged dynamic. After lengthy discussions, the in size and scope. Some additional laws governing the structure of the financial support was forthcoming for universities, both national and private, research and education, but in general have been modified to allow the staff numbers and facilities were not possibility of avoiding the traditional allowed to increase.

This selective funding, however, was koza system, and to admit a more seen to widen the gap between research flexible one. Any new venture has to activities in universities with and with- be discussed with the Ministry of out graduate schools, so great, almost Education, of course.

fanatical, pressures developed in the 1960 s to develop graduate report from the University Council courses. Originally such courses were (Daigaku-setchi Shingikai) in the intended primarily to educate new Ministry of Education is the possibility research scientists, but industry in- of independent graduate institutions creasingly demanded people with outside the universities. Although master's degrees, many of which apparently a reasonable proposal, and courses are now much more closely even though such an institution may related to production processes than be highly qualified in research, there to research.

The market for people with doctorates is limited to universities educational background characteristic and the research institutes of govern- of a university. The lack of a mechment and private industry. But enrol- anism for encouraging interaction ment in higher education seems to be between research and education could reaching saturation, so universities are be harmful. The report also mentioned no longer taking on many new staff; that it would be worth considering the same is true of most other institu- associated graduate institutions adtions, with exceptions only in the en- ministered through the cooperation of vironmental and social sciences. The several universities. Serious efforts problem of the so-called 'over-doctors' are being made in certain groups is serious, and many have proposed an of universities (including cooperation increase in the number of postdoctoral between national and private unifellowships as a way of preserving a versities) to encourage the exchange reservoir of highly qualified manpower of teaching staffs or of student credits. for future demands.

The Japanese concept of the chair useful in developing interdisciplinary (koza) undoubtedly had its origins courses such as information science or in the European professorial chair, environmental science.

although there are many differences.

from Yoshinoku Kakiuchi, Tokyo

Universities offering

$\begin{array}{lcc}\text { Total no. of } & \begin{array}{c}\text { master's } \\ \text { universities }\end{array} & \begin{array}{c}\text { degrees only } \\ \text { National }\end{array} \\ \text { Public } & 33 & 38 \\ \text { Private } & 299 & 4 \\ \text { Total } & 413 & 37 \\ \text { Total } & & 79\end{array}$
master's degrees and doctorates

doctorates only

$\begin{array}{rr}26 & 1 \\ 8 & 7 \\ 72 & 12 \\ 106 & 20\end{array}$

\section{Anti-nuclear critic faces dismissal}

by Allan Piper

A LEAding West German nuclear scientist is faced with dismissal from his chair at the University of Bremen, apparently because of his support for the anti-nuclear energy lobby. Dr Jens Scheer, Professor of Nuclear Physics at Bremen and a state parliamentary candidate for the German communist party (KPD), has claimed that the action against him arises out of his active criticism of the West German nuclear programme, and that it is not a consequence of his political affiliations, as is officially claimed.

Professor Scheer was suspended on September 23 following his alleged involvement in a disturbance on the university campus during which the officials of a civil court were attacked by egg throwers. Though he denies the charge he will now face a special disciplinary tribunal. The University authorities have stated that they are seeking his dismissal, the official reason given being that Professor Scheer, as a member of the KPD, has contravened "the code of honour which every [civil servant] must, through his whole behaviour profess and seek to maintain". Although as head of a university department Professor Scheer holds what is effectively a life appointment under existing German law, his dismissal on those grounds would be perfectly in order. A growing body of support for him maintains, however, that a little used legal clause has been invoked to mask the real reason for dismissal.

Professor Scheer's supporters, including a large number of eminent European academics and political organisations, believe that in seeking to remove him from his position at the university, the authorities hope to overcome a potentially powerful source of opposition to the West German nuclear energy programme. As yet Germany has no nationally coordinated anti-nuclear lobby but in the past Professor Scheer has of ten provided expert support for small, local protest organisations. Further, since his arrival at Bremen in 1971 Professor Scheer has established his department as a centre for the study of the interactions between science, technology and society, and in May this year the department published a book examining the strategy and consequences of nuclear development.

- Yesterday it was learnt that Professor Scheer's suspension has been overruled by a court of law, allowing him to resume his normal duties at the university, but dismissal proceedings will still go ahead. 